\title{
The effect of retinol and retinoic acid on physiological and biochemical changes in retinol-deficient rats
}

\author{
By R. F. KRAUSE, K. C. BEAMER, A. M. MCCORMICK, \\ R. J. CANTERBURY AND G. P. TRYFIATES \\ Department of Biochemistry, West Virginia University Medical Center, \\ Morgantown, West Virginia 26506, USA \\ (Received 2 May 1974-Accepted I4 June 1974)
}

\begin{abstract}
I. The effects of retinol and retinoic acid supplementation of retinol-deficient rats were studied for a variety of metabolic processes shown to be affected by retinol deficiency.

2. Retinol-deficient rats were found to have decreased body-weight, liver and testes weights, a degeneration of testicular germinal cells, an increased incorporation of labelled choline into liver and testes phospholipids, an increased protein synthetic activity (in vitro) of liver ribosomes, an increased transfer-RNA methyltransferase activity in liver and a decreased activity in testes, an increased DNA content of testicular nuclei, and a decreased uptake of $\left[{ }^{3} \mathrm{H}\right]$ thymidine by testicular nuclear DNA.

3. In retinol-deficient rats supplemented for 8 weeks with retinol these changes were reversed, measurements returning to control levels.

4. In retinol-deficient rats supplemented for 8 weeks with retinoic acid all changes were reversed except those in the testes.

5. Testicular signs of retinol deficiency appeared to be delayed when retinoic acid was added to the retinol-deficient diet of weanling rats. This suggests a sparing action of retinoic acid on the rat's utilization of retinol.

6. Suggestions are offered as to why retinoic acid will support growth and development but not spermatogenesis in the rat.
\end{abstract}

It is well documented that either retinol or retinoic acid will support normal growth and development (Moore, 1957) but only retinol will maintain normal vision (Dowling \& Wald, I960) and reproduction (Howell, Thompson \& Pitt, I963).

To obtain more information on the biochemistry of retinol, we have studied the effectiveness of retinol and retinoic acid in alleviating or reversing physiological and biochemical changes associated with retinol deficiency. We have selected a few basic aspects of metabolism in liver and testes, organs known to be affected by retinol deficiency: body- and organ weights, phospholipid metabolism, protein synthesis, activity of transfer-RNA methyl transferases, DNA content of cells and thymidine incorporation into DNA. Changes in these measurements were studied for either liver or testes, or both organs, in groups of control, deficient, retinol- and retinoic acid-supplemented rats. Emphasis was placed on the effectiveness of retinoic acid to substitute for retinol in reversing the changes associated with retinol deficiency.

\section{EXPERIMENTAL}

\section{Animals and diet}

Disease-free, weanling male albino rats of the Wistar Strain were made retinoldeficient as previously described (Krause, Beamer \& Lawrence, I969; Krause, Beamer \& Plow, I971). The animals were kept in individual cages in an air-conditioned room at $24^{\circ}$, with illumination from 06.00 to 8.00 hours. Pair-fed controls were used. The 
non-supplemented rats showed a decrease of $20 \pm 4 \%$ (mean $\pm \mathrm{SD}$ ) in food intake. Animals were considered 'severely deficient' (SD) when they no longer gained weight or began to lose weight. This usually required about Io weeks. Rats were labelled 'mildly deficient' (MD) when their weight gain was reduced to ro-I2 g/week, compared to $30-35 \mathrm{~g} /$ week for ad lib.-fed, normal rats. The livers and plasma from all animals were extracted and their retinol content estimated using the trifluoroacetic acid method (Neeld \& Pearson, I963). All rats were fasted I $2 \mathrm{~h}$ prior to being killed and were killed at the same time of day. All experimental rats, either deficient or supplemented, were matched with controls of the same age.

The composition of the control and deficient diets have been previously described by Krause et al. (I97I).

Supplemented rats. The dietary supplements were introduced after the animals had been given the deficient diet for either 6 or ro weeks and supplementation was continued for either 4 or 8 weeks. The deficient diet was supplemented with $20 \mathrm{mg}$ retinoic acid $/ \mathrm{kg}$ or $6 \mathrm{mg}$ retinol $/ \mathrm{kg}$.

Two groups of rats were made retinol-deficient by feeding weanling rats on a retinol-deficient diet plus $20 \mathrm{mg}$ retinoic acid $/ \mathrm{kg}$ for either Io (mildly deficient, RAMD) or 20 weeks (severely deficient, RASD). Since these animals exhibited a normal growth pattern, assessment of the deficiency state was based on testicular degeneration.

\section{Experimental procedures}

Histological examination of testes. A portion of testis from two animals of each group was fixed in Bouin's solution, dehydrated with ethanol, embedded using standard procedures and sections stained with haematoxylin and eosin. Gradation of the degree of testicular damage was based on the criteria of Mason (1926).

In general, retinol deficiency begins with signs of degenerating spermatozoa (stage 1 ), followed in order by: the absence of spermatozoa and early signs of degenerating spermatids (stage 2); fusion of spermatid nuclei and 'giant cell' formation (stage 3 ); absence of spermatids and signs; of degenerating spermatocytes and spermatogonia (stage 4); and finally the disappearance of all germinal cells (stage 5).

Mild deficiency is characterized by stages 2-3 and severe deficiency by stages $4-5$.

Preparation of subcellular fractions. All animals were killed by a blow on the head and immediately decapitated. The livers were perfused with cold saline ( $9 \mathrm{~g} \mathrm{NaCl} / \mathrm{l})$, removed, weighed and placed in cold $0.25 \mathrm{M}$-sucrose containing I $\mu \mathrm{M}$-EDTA and adjusted to $\mathrm{pH} 7.8$ with $0.5 \mathrm{M}$-Tris (hydroxymethyl) methylamine, then homogenized in $4.5 \mathrm{ml}$ sucrose medium/g tissue and the subcellular fractions separated by differential centrifugation and identified by enzyme markers (e.g. mitochondria by $\alpha$-ketoglutarate dehydrogenase $(E C \quad \mathbf{I} .2 .4 .2)$ and microsomes by glucose-6-phosphatase (EC 3.I.3.9) and by electron microscopy as previously described (Krause et al. I97I)).

The testes were removed, chilled to $0-4^{\circ}$, freed of capsule, weighed and homogenized in $1.9 \mathrm{ml}$ cold $0.25 \mathrm{M}$-sucrose medium/g tissue as described for liver. Subcellular fractions were prepared by differential centrifugation as described above and the 
fractions identified by electron microscopy and enzyme markers as described for liver.

Protein determination. The method of Lowry, Rosebrough, Farr \& Randall (195I) was used for this measurement.

Lipid extraction. The extraction of lipid from the various subcellular fractions was done using chloroform-methanol (2:I, v/v) (Folch, Lees \& Sloane Stanley, I957).

Isolation of phospholipids. The extracted and washed lipids were fractionated by silicic acid column chromatography (Hirsch \& Ahrens, I958) and thin-layer chromatography (Krause et al. 1971). Phosphorus determinations on phospholipid samples were done by the method of Chen, Yoribara \& Warner (1956).

Administration of labelled compounds. $\left[{ }^{14} \mathrm{CH}_{3}\right]$ choline (New England Nuclear, Boston, Mass. USA) was dissolved in saline $(9 \mathrm{~g} \mathrm{NaCl} / 1)$ and $0.046 \mu \mathrm{Ci}(0.00 \mathrm{I}$ $\mu \mathrm{mol}) / \mathrm{g}$ body-weight was injected intraperitoneally.

$\left[{ }^{3} \mathrm{H}-\mathrm{CH}_{3}\right]$ thymidine (specific activity $20 \mathrm{Ci} / \mathrm{mmol}$ ) (New England Nuclear, Boston, Mass., USA) was dissolved in ethanol--water $(7: 3, \mathrm{v} / \mathrm{v})$ and $0.5 \mu \mathrm{Ci}(0.025 \mathrm{nmol}) / \mathrm{g}$ body-weight was injected intraperitoneally. This dose was $0.1-0.3 \mathrm{ml} / \mathrm{rat}$.

Preparation of liver ribosomes. Polyribosomes were prepared from rat liver essentially by the method of Blobel \& Potter ( 1967 ). The pelleted material sedimenting through the $2.0 \mathrm{M}$-sucrose at $105000 \mathrm{~g}$ for $\mathrm{I} 8 \mathrm{~h}$ was used in protein synthesis experiments within $6 \mathrm{~h}$ of preparation.

For the preparation of the ' $\mathrm{pH} 5 . \mathrm{I}$ fraction' the $17000 \mathrm{~g}$ 'post-mitochondrial' supernatant fraction was further centrifuged at $144800 \mathrm{~g}$ for $2 \mathrm{~h}$ and the supernatant fraction diluted with 2 vol. of a medium containing $0.9 \mathrm{M}$-sucrose, $0.004 \mathrm{M}$-magnesium acetate, $0.07 \mathrm{M}-\mathrm{KCl}$ and $0.006 \mathrm{M}-2$-mercaptoethanol. The $\mathrm{pH}$ was adjusted to $5 . \mathrm{I}$ with 0.1 M-acetic acid. The precipitate was washed with cold, twice-distilled water and used within $6 \mathrm{~h}$ of preparation.

Procedure for the estimation of protein synthetic activity in vitro. Protein synthetic activity was determined by the method previously described by Tryfiates (1969), Tryfiates (1971) and Tryfiates \& Krause (1971 $a$ ). Incubation was done at $37^{\circ}$, and $\mathrm{I} \cdot 0 \mathrm{mg}$ ribosomes, $2.4 \mathrm{mg}$ enzyme protein (' $\mathrm{pH} 5 . \mathrm{I}$ fraction'), and $0.4 \mu \mathrm{Ci}$ $\mathrm{L}-\left[{ }^{3} \mathrm{H}\right]$ phenylalanine (specific activity $2 \mathrm{Ci} / \mathrm{mmol}$; Schwartz-Mann, Orangeburg, New York, USA) were included in $0.67 \mathrm{ml}$ of incorporation system. Incorporation of radioactivity into hot trichloroacetic acid-insoluble protein was determined by the method of Mans \& Novelli (196r). Radioactivity was measured using a Tri-Carb liquid scintillation spectrometer (Packard Instrument Co. Inc., Downers Grove, Illinois, USA) and corrected for background and quenching. Protein was measured by the method of Lowry et al. (I95I).

Ribosome concentration was estimated using an extinction at $260 \mathrm{~nm}$ of $\mathrm{r} \cdot \mathrm{O}$ as being equivalent to $90 \mu \mathrm{g}$ ribosomes (Martin, Rolleston, Low \& Wool, I969).

In vitro polymerization of $\mathrm{L}-\left[{ }^{3} \mathrm{H}\right]$ phenylalanine was performed in the presence and absence of polyuridylic acid (poly-U). All poly-U estimations were done using preincubated ribosomes $\left(40 \mathrm{~min}, 37^{\circ}\right.$ ) with $100 \mu \mathrm{g}$ poly-U (Sigma Chemical Co., St Louis, Missouri, USA) per estimation. 
Preparation of transfer-RNA methyltransferase substrates of liver and testes. S$\left[{ }^{14} \mathrm{CH}_{3}\right]$ adenosyl-L-methionine (ICN Pharmaceuticals, Irwine, California, USA) with a specific activity of $52 \mathrm{mCi} / \mathrm{mmol}$, was diluted $\mathrm{I}: 20(\mathrm{w} / \mathrm{v})$ with $\mathrm{I}$ mM-acetic acid, $\mathrm{pH} 4.0$ and stored frozen $\left(-32^{\circ}\right)$ until used. Unlabelled S-adenosyl-L-methionine was purchased from Sigma Chemical Co., St Louis, Missouri, USA. Crystalline Escherichia coli B transfer-RNA (stripped) (General Biochemicals, Chagrin Falls, Ohio, USA) was kept frozen $\left(-32^{\circ}\right)$ until used. A working solution of this material was prepared by dissolving $\mathrm{I} \mathrm{mg} / \mathrm{ml}$ distilled water and kept frozen $\left(-32^{\circ}\right)$ until used.

Preparation of crude transfer-RNA methyltransferases. Rats were killed as described previously, their livers were perfused with cold saline, excised, and rapidly chilled in cold saline. The testes were excised, chilled, stripped of capsule and placed in cold saline. All tissues were homogenized in 4 vol. 0.0 r M-Tris- $\mathrm{HCl}$ buffer, $\mathrm{pH} 7 \cdot 4$ containing $0 . \mathrm{I} \mathrm{M}-\mathrm{MgCl}_{2}$ and $0.005 \mathrm{M}$-2-mercaptoethanol in an all-glass Dounce homogenizer. Homogenates were then spun at $15000 \mathrm{~g}$ for $10 \mathrm{~min}$ in a refrigerated centrifuge. The supernatant fraction was centrifuged at $105000 \mathrm{~g}$ for $\mathrm{Ih}$ and the resultant supernatant fraction was used as a source of the crude transfer-RNA methyltransferases.

Procedure for the estimation of transfer-RNA methyltransferase activity. The procedure used was a modification of the procedures of Mandel \& Borek (196I) and Kerr (1970). For liver, a reaction mixture ( $\mathrm{r} \mathrm{ml}$ ) containing $10 \mathrm{mmol}$ Tris $-\mathrm{HCl}$ buffer, $\mathrm{pH} 8.0,5 \mathrm{mmol} 2$-mercaptoethanol, roo $\mu \mathrm{g} \mathrm{E}$. coli B transfer-RNA, $2 \cdot 0 \mathrm{mg}$ of the control, deficient or deficient-supplemented crude enzyme and $59 \mathrm{nCi} \mathrm{S}-\left[{ }^{14} \mathrm{CH}_{3}\right]-$ adenosyl-L-methionine was incubated for $120 \mathrm{~min}$ (time for maximum incorporation) at $37^{\circ}$. For testes, a $\mathrm{I} \mathrm{ml}$ reaction mixture containing $10 \mathrm{mmol}$ Tris- $\mathrm{HCl}$ buffer,

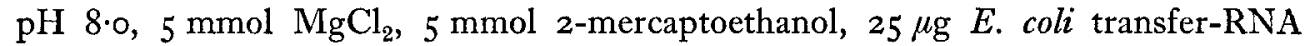
(methyl-deficient, prepared by growing methionine-requiring $E$. coli mutants in the absence of methionine (Harris, 1970) and extracting the transfer-RNA by the method of Von Ehrenstein (1967)), , $00 \mathrm{nCi} \mathrm{S-}\left[{ }^{4} \mathrm{CH}_{3}\right]$ adenosyl-L-methionine and $2 \cdot 0 \mathrm{mg}$ of control, deficient or deficient-supplemented crude enzyme was incubated for $3 \mathrm{~h}$ at $37^{\circ}$.

Isolation of testicular nuclei. The capsule was removed from the testis and the testicular mass homogenized with a glass homogenizer, using the procedure of Blobel \& Potter (1966) with some modifications. The homogenate was prepared using $2 \mathrm{ml}$ $0.25 \mathrm{M}$-sucrose in a buffer containing $0.05 \mathrm{M}$ Tris- $\mathrm{HCl}, \mathrm{pH} 7.5,0.025 \mathrm{M}-\mathrm{KCl}$ and $0.005 \mathrm{M}-\mathrm{MgCl}_{2}$ (TKM)/g tissue, then $7 \mathrm{ml}$ of this homogenate was thoroughly mixed with $14 \mathrm{ml} \mathrm{2.3}$ M-sucrose in TKM buffer, underlayed with $10 \mathrm{ml} 2.3 \mathrm{M}$-sucrose in TKM, and centrifuged for $90 \mathrm{~min}$ at $63000 \mathrm{~g}$ to produce a good isolation of testicular nuclei by density-gradient separation.

Counting nuclei. The final pellets of testicular nuclei were suspended in $5 \mathrm{ml} 0.25 \mathrm{M}-$ sucrose in TKM buffer and stored at $4^{\circ}$. The number of nuclei in this suspension were counted using a haemocytometer.

Determination of DNA content of nuclei. In the preparation of nuclei for counting it was noted that some nuclei had ruptured, especially nuclei from retinol-deficient 
rats, and had released nuclear DNA into the suspending medium. Therefore, to measure the DNA content of nuclei, it was necessary to determine the total DNA content of the nuclear suspension and to determine the amount of DNA in the corresponding supernatant fraction which was free of nuclei. The DNA content of whole nuclei was then calculated by subtracting 'supernatant' DNA from the total DNA of the nuclear suspension.

The DNA content of the various fractions was determined by the method of Burton (1968). The DNA was extracted with $0.5 \mathrm{M}$-perchloric acid at $90^{\circ}$ for $30 \mathrm{~min}$. The extract was diluted with $0.5 \mathrm{M}$-perchloric acid so that the final solution contained between 0.02 and $0.25 \mu \mathrm{mol}$ DNA-phosphate $/ \mathrm{ml}$. Suitable portions were mixed with 2 vol. diphenylamine reagent. Standard and blanks were similarly prepared.

All tubes were incubated for $5 \mathrm{~h}$ at $35^{\circ}$ and the extinction at $600 \mathrm{~nm}$ was measured.

Isolation of DNA from testicular nuclei. The procedure of Marmur (196r) was used for the isolation of DNA from testicular nuclei.

Thymidine incorporation into nuclear DNA of testes. All rats used for this measurement were fasted for $24 \mathrm{~h}$ before they were killed and $7 \mathrm{~h}$ before the termination of the experiment they were injected intraperitoneally with $0.5 \mu \mathrm{Ci}(0.025 \mathrm{nmol})\left[{ }^{3} \mathrm{H}_{-}-\mathrm{CH}_{3}\right]-$ thymidine in ethanol-water $(7: 3, \mathrm{v} / \mathrm{v}) / \mathrm{g}$ body-weight. This $7 \mathrm{~h}$ lapse time allowed for one complete cycle of DNA replication in the rat (Cameron, 1968). After killing the rats, their testes were excised and kept in cold saline at $0-4^{\circ}$ until they were decapsulated.

Radioactive counting of DNA. To prepare the samples for liquid scintillation counting, either I ml of a nuclear suspension or an equivalent amount of isolated DNA was hydrolysed by adding I $\mathrm{ml} \mathrm{I} \cdot \mathrm{O} \mathrm{M}$-perchloric acid in a closed tube and heating to $85-90^{\circ}$ for $30 \mathrm{~min}$. The supernatant fraction contained the labelled nucleotides. To $0.2 \mathrm{ml}$ of this supernatant fraction was added $\mathrm{r} 0 \mathrm{ml}$ of Ready-Solv Solution IV (Beckman Instruments Inc., Pittsburgh, Pennsylvania, USA) scintillation fluid and the radioactivity counted using a liquid scintillation spectrometer and corrected for background and quenching. The radioactivity was reported as counts/min per $\mu \mathrm{g}$ of either isolated DNA or DNA of a nuclear hydrolysate.

\section{RESULTS}

\section{Body-weight and organ weights}

A comparison of body-weight, liver and testes weights of control, deficient, and retinol- and retinoic acid-supplemented rats is shown in Table $\mathrm{I}$.

Deficient animals. SD rats lost weight and had smaller livers and testes than the respective control rats. Their liver weight:body-weight ratios increased while their testes weight:body-weight ratios decreased compared to the control group. The testes of the SD group showed extreme degeneration of the germinal epithelium.

There were no significant differences between MD rats and control rats except that the testes of the MD group had no spermatozoa.

Supplemented animals. Body-weights and organ weights of SD rats returned to control values by 8 weeks of retinol supplementation. In contrast in SD rats after 8 


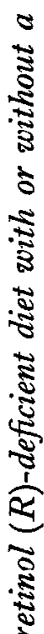

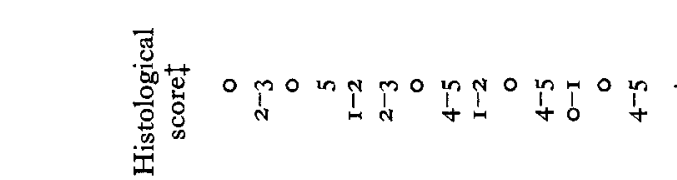

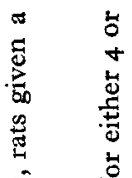

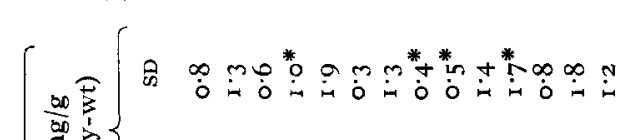

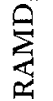

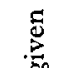

还

西

离

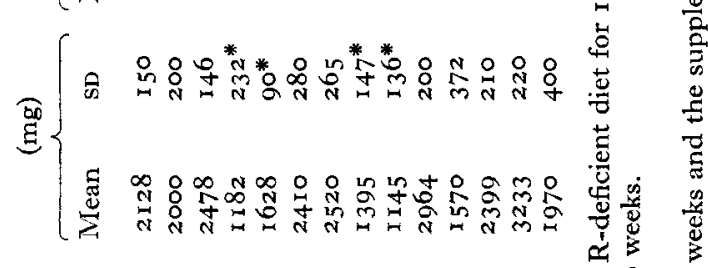

: 势

:

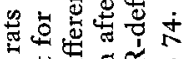


Table 2. Liver and plasma retinol concentrations in weanling rats given a control diet or a retinol $(R)$-deficient diet with or without a supplement of retinol or retinoic acid $(R A)$

(Mean values and standard deviations)

\begin{tabular}{|c|c|c|c|c|c|c|}
\hline \multirow[b]{2}{*}{ Group* } & \multirow{2}{*}{$\begin{array}{l}\text { No. of } \\
\text { rats }\end{array}$} & \multicolumn{2}{|c|}{$\begin{array}{l}\text { Liver } \\
(\mu \mathrm{g} / \mathrm{g})\end{array}$} & \multicolumn{3}{|c|}{$\begin{array}{l}\text { Plasma } \\
(\mu \mathrm{mol} / 1)\end{array}$} \\
\hline & & Mean & SD & Mean & & SD \\
\hline \multicolumn{7}{|l|}{ Controls } \\
\hline C-62 & 4 & 355 & I I & $x \cdot 36$ & & 0.45 \\
\hline C-9o & 6 & 462 & $3 I$ & $2 \cdot 06$ & & 0.42 \\
\hline C-I I 8 & 4 & $47^{\circ}$ & 25 & I*99 & & 0.49 \\
\hline$C-146$ & 4 & 477 & $3 I$ & $2 \cdot 02$ & & 0.52 \\
\hline C-I6o & 3 & 472 & 20 & $2 \cdot 06$ & & 0.45 \\
\hline \multicolumn{7}{|l|}{ Deficient } \\
\hline SD & 6 & nd & & & nd & \\
\hline MD & 4 & $2 \cdot 5$ & 0.2 & & nd & \\
\hline RAMD & 4 & $I \cdot 5$ & 0.3 & & nd & \\
\hline RASD & 4 & nd & & & nd & \\
\hline \multicolumn{7}{|c|}{ Supplemented } \\
\hline $\mathbf{S D}+{ }_{4} \mathbf{R A}$ & 4 & nd & & & nd & \\
\hline $\mathrm{SD}+8 \mathrm{RA}$ & 4 & nd & & & nd & \\
\hline $\mathrm{SD}+4 \mathrm{R}$ & 4 & 235 & II & $I \cdot 57$ & & 0.21 \\
\hline $\mathrm{SD}+8 \mathrm{R}$ & 4 & 270 & 45 & $I \times 92$ & & 0.35 \\
\hline $\mathrm{MD}+{ }_{4} \mathrm{R}$ & 4 & 230 & 14 & $1 \cdot 75$ & & 0.24 \\
\hline
\end{tabular}

$\mathrm{C}$, control; MD, mildly-deficient rats given a R-deficient diet for 6 weeks; SD, severely-deficient rats given a R-deficient diet for ro weeks; RAMD, rats given a R-deficient diet $+20 \mathrm{mg} \mathrm{RA} / \mathrm{kg}$ diet for Io weeks; RASD, rats given a R-deficient diet $+20 \mathrm{mg} \mathrm{RA} / \mathrm{kg}$ diet for 20 weeks; nd, not detected, i.e. retinol concentration of liver $<0.05 \mu \mathrm{g} / \mathrm{g}$ and plasma $<0.035 \mu \mathrm{mol} / 1$.

* For details of groups, see Table $\mathrm{x}$.

weeks of retinoic acid supplementation, body-weights and liver weights returned to control values but testes weights were not affected.

\section{Retinol concentration in liver and plasma}

The liver and plasma retinol concentrations of control, deficient and supplemented rats are summarized in Table 2. It is apparent that there were adequate amounts of retinol in the livers and plasma of control and retinol-supplemented rats. No retinol was detected in either the livers or plasma of SD rats. The MD rats contained a small quantity of retinol in their livers but none was detected in their plasma. Deficient rats supplemented with retinoic acid contained no detectable amounts of retinol in either their livers or plasma. Those rats given the RAMD diet had a low concentration of retinol in their livers but none in their plasma.

\section{Phospholipid metabolism of subcellular fractions from liver and testes}

A comparison of the specific activities of phospholipids from subcellular fractions of liver and testes from control, deficient, retinol- and retinoic acid-supplemented rats, $6 \mathrm{~h}$ after an injection of labelled choline is shown in Table 3 .

It should be noted that the $6 \mathrm{~h}$ post-injection time represented the approximate maximal specific activity for the liver (Krause \& Beamer, 1972) but not for the testes. 
In the latter organ $12 \mathrm{~h}$ were required for maximum incorporation of labelled choline in both control and deficient rats (Krause \& Beamer, unpublished work). Since we were primarily concerned with comparing specific activities of the same organ under different experimental conditions, it seemed appropriate and convenient to use both organs from the same experimental animal. Therefore, the $6 \mathrm{~h}$ post-injection time was used for both testes and liver.

Control and deficient animals. As previously reported (Krause \& Beamer, 1972) and as seen in Table 3 , retinol deficiency results in an increased uptake of choline in all subcellular phospholipids of testes and liver. The incorporation of $\left[{ }^{14} \mathrm{CH}_{3}\right]$ choline was much higher in the liver phospholipids of the MD group than in those of the SD group. This difference may possibly reflect a decrease in the enzymes involved in liver phospholipid biosynthesis of SD rats.

In contrast the uptake of labelled choline by testicular phospholipids was higher in the $\mathrm{SD}$ group compared to the $\mathrm{MD}$ group. This reflects a progressive increase in testicular phospholipid biosynthesis with increased retinol deficiency. At present no explanation is apparent for this effect.

In the liver the highest specific activity was found in the microsomes, while in the testes it was in the soluble fraction. In all instances the mean values for specific activity of subcellular phospholipids at $6 \mathrm{~h}$ was higher in liver than in testes.

Retinol-and retinoic acid-supplemented animals. When MD rats were supplemented with either retinol or retinoic acid for 4 weeks, the specific activity of all liver subcellular phospholipids labelled with choline returned to control values. In contrast only retinol supplementation for 4 weeks resulted in the return of testicular subcellular phospholipid values to those of the controls.

Likewise, when the SD rats were supplemented with either retinol or retinoic acid for 4 weeks, the specific activities of all subcellular phospholipids were similar to those of the controls. In contrast to the $\mathrm{MD}$ group, the $\mathrm{SD}$ rats required 8 weeks of retinol supplementation to return their testicular phospholipid specific activity values to those of the controls. Retinoic acid was not effective in this regard.

Even though retinoic acid was not effective in reversing the testicular changes associated with retinol deficiency, it did retard their development. For example, the results in Table 3 show that the ro-week addition of retinoic acid to the retinoldeficient diet of weanling rats (RAMD) prevented the development of testicular phospholipid changes found in rats given a deficient diet alone for ro weeks. However, if the deficient diet plus retinoic acid supplement were fed for 20 weeks (RASD) then the testicular changes were found.

It is worthy of note that the specific activity of liver subcellular phospholipids remained similar to the control values for both groups of rats given a deficient diet + retinoic acid for either ro or 20 weeks.

\section{Protein synthetic activity of retinol-deficient rat liver ribosomes supplemented with retinoic acid}

Table 4 summarizes the influence of feeding retinoic acid to retinol-deficient rats on the in vitro protein synthetic activity of rat liver ribosomes in the presence and 
Table 4. The effect of retinoic acid supplementation of severely rutinol-deficient weanling rats on the in vitro protein synthetic activity of liver ribosomes in the presence and absence of a synthetic messenger-RNA (poly-U)

(Mean values and standard deviations for groups of six tats : no. of determinations in parentheses)

\begin{tabular}{|c|c|c|c|c|}
\hline \multirow[b]{3}{*}{ Group } & \multicolumn{4}{|c|}{$\begin{array}{c}\text { In vitto incorporation of } \mathrm{L}-\left[{ }^{3} \mathrm{H}\right] \text { phenylalanine into ribosomal } \\
\text { protein* (counts/min per mg ribosomal protein) }\end{array}$} \\
\hline & \multicolumn{2}{|c|}{ With poly-U } & \multicolumn{2}{|c|}{ Without poly-U } \\
\hline & Mean & SD & Mean & SD \\
\hline $\begin{array}{l}\text { Control } \\
\text { Deficient } \dagger \\
\text { Retinoic acid-supplemented }+\end{array}$ & $\begin{array}{l}15571 \\
18500 \\
15280\end{array}$ & $\begin{array}{l}667(4) \\
\text { I I } 00(4) \\
3099(4) \S\end{array}$ & $\begin{array}{l}19431 \\
43000 \\
16152\end{array}$ & $\begin{array}{l}1422(4) \\
5000(4) \\
1740(4)\end{array}$ \\
\hline
\end{tabular}

absence of synthetic messenger-RNA (poly-U). These results confirm our previous observation (Tryfiates \& Krause, I97I $a$ ) that retinol deficiency enhances the in vitro capacity of rat-liver ribosomes to make protein and that this effect is due to the ' $\mathrm{pH} 5^{-\mathrm{I}}$ ' enzyme. Supplementation of the deficient animals with retinoic acid for 8 weeks returned the protein synthetic activity of rat-liver ribosomes in the presence and absence of poly- $U$ to that of the controls. Retinol supplementation of deficient animals for 8 weeks likewise returned protein synthetic activity to that of the controls.

\section{Liver and testes transfer-RNA methyltransferases from control, deficient and supplemented animals}

The results presented in Table 5 show that there was increased transfer-RNA methyltransferase activity in liver and decreased methyltransferase activity in the testes of deficient rats. Supplementation with either retinol or retinoic acid for 8 weeks restored the liver methyltransferase activity in deficient animals to control values but only retinol supplementation of deficient rats restored the testicular methyltransferase activity to control values.

\section{DNA content of testicular nuclei from control, deficient and supplemented animals}

The DNA content of testicular nuclei from control, deficient and supplementeddeficient rats is recorded in Table 6. According to these results, retinol deficiency resulted in a 2-fold increase in the DNA content of testicular nuclei.

It may be seen from Table 6 that retinoic acid supplementation of deficient rats for 8 weeks did not restore the DNA content of testicular nuclei to normal levels, while 8 weeks of retinol supplementation produced testicular nuclei with normal DNA content. 
Table 5. The effect of retinoic acid and retinol supplementation of severely retinol-deficient weanling rats on transfer-RNA methytransferase activity of liver and testes

(Mean values and standard deviations for groups of four rats)

In vitro incorporation of ${ }^{14} \mathrm{CH}_{3}$ groups from S-[$\left[{ }^{14} \mathrm{CH}_{3}\right]$ adenosyl$\mathrm{L}$-methionine into transfer-RNA $\dagger$ ( $\mathrm{nmol} / \mathrm{mg}$ protein)

Group*

Control

Deficient

Retinoic acid-supplemented

Retinol-supplemented

\begin{tabular}{|c|c|c|c|}
\hline \multicolumn{2}{|c|}{ Liver } & \multicolumn{2}{|c|}{ Testes } \\
\hline Mean & SD & Mean & SD \\
\hline $3 \cdot 47$ & 0.09 & $68 \cdot 6$ & $4 \cdot 3$ \\
\hline 5.00 & 0.16 & I3.O & $I \cdot 3$ \\
\hline 3.60 & 0.09 & 10.3 & $I \cdot O$ \\
\hline 3.12 & 0.1 I & $72 \cdot 5$ & $5^{\circ} \circ$ \\
\hline
\end{tabular}

* Deficient, rats made severely deficient by feeding a retinol-deficient diet for ro weeks; retinoic acid-supplemented, rats given a retinol-deficient diet for 1o weeks, then supplemented with $20 \mu \mathrm{g}$ retinoic acid $/ \mathrm{kg}$ retinol-deficient diet for 8 weeks; retinol-supplemented, rats given a retinol-deficient diet for 10 weeks, then supplemented with $6 \mu \mathrm{g}$ retinol $/ \mathrm{kg}$ retinol-deficient diet for 8 weeks.

+ For details of procedure, see p. 76 .

Table 6. DNA content of testicular nuclei from weanling rats given a control diet or a retinol-deficient diet with or without a supplement of retinol or retinoic acid, and the in vitro incorporation of $\left[{ }^{3} \mathrm{H}\right]$ thymidine into testicular nuclear-DNA

\begin{tabular}{|c|c|c|c|c|c|}
\hline \multirow[b]{2}{*}{ Groupt } & \multirow[b]{2}{*}{$\begin{array}{l}\text { No. of } \\
\text { rats }\end{array}$} & \multicolumn{2}{|c|}{$\begin{array}{l}\text { DNA content } \\
\text { (pg/nucleus) }\end{array}$} & \multicolumn{2}{|c|}{$\begin{array}{c}\text { In vitro incorporation of } \\
{\left[{ }^{3} \mathrm{H}\right] \text { thymidine } f \text { (counts } / \mathrm{m}} \\
\text { per } \mu \mathrm{g} \text { DNA) }\end{array}$} \\
\hline & & Mean & $\mathrm{SD}_{\mathrm{SD}}$ & Mean & sD \\
\hline Control & 4 & $6 \cdot 5$ & $1 \cdot 2$ & 25.9 & $6 \cdot 0$ \\
\hline $\begin{array}{l}\text { Deficient } \\
\text { Retinoic acid- }\end{array}$ & 5 & 13.5 & $0.6^{*}$ & $1 \cdot 4$ & $0 . I^{*}$ \\
\hline supplemented & 4 & $29 \cdot I$ & $0.4^{*}$ & 0.3 & $0.1^{*}$ \\
\hline Retinol-supplemented & 4 & $5 \cdot I$ & 0.4 & $24 \cdot 5$ & $1 \cdot 4$ \\
\hline
\end{tabular}

Mean value significantly different from control value: $* P<0.05$.

$\dagger$ Deficient, rats made severely deficient by feeding a retinol-deficient diet for ro weeks; retinoic acid-supplemented, rats given retinol-deficient diet for to weeks, then supplemented with $20 \mu \mathrm{g}$ retinoic acid $/ \mathrm{kg}$ retinol-deficient diet for 8 weeks; retinol-supplemented, rats given a retinol-deficient diet for to weeks, then supplemented with $6 \mu \mathrm{g}$ retinol $/ \mathrm{kg}$ retinol-deficient diet for 8 weeks.

$\ddagger$ For details of procedure, see p. 77. The specific activities were determined on both isolated DNA and DNA of respective nuclear hydrolysates.

\section{Incorporation of labelled thymidine into DNA of testes of control, deficient and supplemented animals}

Testicular DNA from retinol-deficient rats exhibited about an I8-fold decrease in the $\left[{ }^{3} \mathrm{H}-\mathrm{CH}_{3}\right]$ thymidine incorporation into nuclear DNA (counts/min per $\mu \mathrm{g} \mathrm{DNA}$ ), when compared with control values (Table 6).

When the retinol-deficient rats were supplemented with either retinol or retinoic acid for 8 weeks, only retinol treatment restored the incorporation of labelled thymidine by testicular DNA to control levels.

In control, deficient and supplemented animals the specific activities (counts/min per $\mu \mathrm{g}$ DNA) of isolated DNA and DNA of respective nuclear hydrolysates were essentially the same. 
DISCUSSION

Some physical and biochemical changes caused by retinol deficiency were reversed after 8 weeks of retinol treatment, while a similar period of treatment with retinoic acid restored growth and development to approximately normal levels and appeared to reverse changes in liver associated with retinol deficiency; it did not, however, correct any of the changes associated with the deficiency state in the testes. Supplementation of retinol-deficient diets with retinoic acid has been advocated to avoid secondary complicating effects of general inanition in acute retinol deficiency (Bieri \& Prival, I966). In experimental groups RAMD and RASD, where deficiency was judged by the weight and histological appearance of the testes, we found that the testicular changes produced by this diet were similar to those in animals made deficient with a retinol-deficient diet alone. Therefore, it seems unlikely that the testicular changes associated with retinol deficiency are the result of inanition or decreased food consumption.

Retinoic acid supplementation of the deficient diet appeared to delay the onset of testicular deficiency signs, when compared to the group given the deficient diet alone: rats on a deficient diet for to weeks became severely deficient while rats on the deficient diet plus retinoic acid for the same period of time became only mildly deficient (Tables I and 2). These observations support the findings of Zile \& DeLuca (1968) that retinoic acid has a sparing effect on retinol and are in contrast to the report of Dowling \& Wald (1960), that the rate of retinol depletion in the liver is equally rapid, whether or not retinoic acid is available.

Ahluwalia, Devi \& Clark (1973) found that retinol is selectively absorbed by the seminiferous tubules but retinoic acid is not. This implies that retinoic acid does not support spermatogenesis because it is not absorbed by the seminiferous tubules, although Ahluwalia \& Bieri (197I) have found that the intratesticular injection of retinoic acid does not stimulate spermatogenesis in retinol-deficient rats, while a similar injection of retinol will produce evidence of local regeneration. It is possible that these effects are also the result of different binding properties of retinol and retinoic acid to the seminiferous tubules.

In our previous studies of retinol metabolism we found that a lack of this vitamin results in: (1) increased protein synthesis by the liver (Tryfiates \& Krause, 1971 $a$ ) and (2) altered messenger RNA in liver cells (Tryfiates \& Krause, 1971 $b$ ). In the present report we have found:(I) increased transfer-RNA methyltransferase activity in liver and decreased activity in testes; (2) increased DNA in nuclei testicular cells and (3) decreased $\left[{ }^{3} \mathrm{H}-\mathrm{CH}_{3}\right]$ thymidine incorporation into DNA of testicular nuclei.

Sundaresan (1972) has recently enumerated the many enzymes reported to be affected by retinol deficiency and has pointed out how they relate to carbohydrate, lipid and protein metabolism.

All these biochemical signs of retinol deficiency seem to be related either directly or indirectly to protein synthesis. Therefore, it would appear that retinol's main function is in some manner to regulate protein synthesis. 
Hayes (I97I) has suggested that retinol exerts its influence during differentiation of both epithelial and mesenchymal cells. A variety of factors affect the differentiation process (Rutter, Pictet \& Morris, 1973): replication, transcription and translation. All these processes have been shown to be affected by retinol deficiency. Therefore, it seems logical to search for the metabolic role of this vitamin along these lines, especially at the DNA level.

In this report we have confirmed a previous observation (Rapoport, Kuznetsova \& Dubrova, 1972) that rats deficient in vitamin A have increased levels of DNA in testicular nuclei. This suggests that retinol deficiency may affect the metabolism of nuclear DNA, either by increased synthesis or decreased degradation. The decreased incorporation of $\left[{ }^{3} \mathrm{H}-\mathrm{CH}_{3}\right]$ thymidine into DNA of deficient rat testes would reduce the possibility of increased synthesis.

The support of this work by the US Public Health Service Grant AM-Ir597 and CA 13759 is gratefully acknowledged.

\section{REFERENCES}

Ahluwalia, B. \& Bieri, J. G. (1971). F. Nutr. I01, 141.

Ahluwalia, B., Devi, A. \& Clark, J. F. J. (1973). Fedn Proc. Fedn Am. Socs exp. Biol. 32, 947.

Bieri, J. G. \& Prival, E. L. (I966). F. Nutr. 89, 55.

Blobel, G. \& Potter, V. R. (1966). Science, N.Y. 154, 1662.

Blobel, G. \& Potter, V. R. (1967). F. molec. Biol. 26, 279.

Burton, K. (1 g68). Meth. Enzym. 12 B, 163 .

Cameron, I. L. (1968). In Methods in Cell Physiology Vol. 3, p. 263 [D. M. Prescott, editor]. New York: Academic Press Inc.

Chen, P. S., Yoribara, T. Y. \& Warner, H. (1956). Analyt. Chem. 28, 1756.

Dowling, J. E. \& Wald, G. (1960). Proc. Natn. Acad. Sci. U.S.A. 46, 587.

Folch, J., Lees, M. \& Sloane Stanley, G. H. (1957). F. biol. Chem. 226, 497.

Harris, C. L. (1970). Sulfur-deficient transfer ribonucleic acid. PhD Thesis, University of Illinois, Chicago, Illinois.

Hayes, K. C. (197I). Nutr. Rev. 29, 3 .

Hirsch, J. \& Ahrens, E. H. Jr (1958). F. biol. Chem. 233, 31 I.

Howell, J. McC., Thompson, J. N. \& Pitt, G. A. J. (1963). Y. Reprod. Fert. 5, I59.

Kerr, S. J. (1970). Biochemistry, Easton 9, 690.

Krause, R. F. \& Beamer, K. C. (1972). $\mathscr{F}$. Nutr. 102, 1465.

Krause, R. F., Beamer, K. C. \& Lawrence, C. (1969). Am. F. clin. Nutr. 22, 27.

Krause, R. F., Beamer, K. C. \& Plow, J. H. (1971). F. Nutr. ror, I61.

Lowry, O. H., Rosebrough, N. J., Farr, A. L. \& Randall, R. J. (I95I). J. biol. Chem. 193, 265.

Mandel, L. R. \& Borek, E. (1961). Biochem. biophys. Res. Commun. 6, I38.

Mans, R. J. \& Novelli, G. D. (I961). Archs Biochem. Biophys. 94, 48.

Marmur, J. (r96r). F. molec. Biol. 3, 208.

Martin, T. E., Rolleston, F. S., Low, R. B. \& Wool, I. G. (1969). J. molec. Biol. 43, 135.

Mason, K. E. (1926). F. exp. Zool. 45, I59.

Moore, T. (1957). Vitamin $A$ p. 282. Amsterdam: Elsevier.

Neeld, J. B. \& Pearson, W. N. (1963). F. Nutr. 79, 454.

Rapoport, B. N., Kuznetsova, Z. A. \& Dubrova, N. B. (1972). Uchen. Zap. gorkov. gos. Univ. 140, 129.

Rutter, W. J., Pictet, R. L. \& Morris, P. W. (1973). A. Rev. Biochem. 42, 6or.

Sundaresan, P. R. (I972). 7. scient. ind. Res. 31, 581.

Tryfiates, G. P. (1969). Biochim. biophys. Acta 174, 779.

Tryfiates, G. P. (1971). Biochem. Pharmac. 20, I669.

Tryfiates, G. P. \& Krause, R. F. ( (97 г a). Proc. Soc. exp. Biol. Med. 136, 946.

Tryfiates, G. P. \& Krause, R. F. (197 I b). Life Sci. ro, ro97.

Von Ehrenstein, G. (1967). Meth. Enzym. 12, 588.

Zile, M. \& DeIuca, H. F. (1968). F. Nutr. 94, 302 . 